University of Northern lowa

UNI ScholarWorks

Faculty Publications

Faculty Work

1978

\title{
On Visual Art and Camouflage
}

Roy R. Behrens

University of Northern lowa

Let us know how access to this document benefits you

Copyright (C)1978 The MIT Press

Follow this and additional works at: https://scholarworks.uni.edu/art_facpub

Part of the Art and Design Commons

\section{Recommended Citation}

Behrens, Roy R., "On Visual Art and Camouflage" (1978). Faculty Publications. 7.

https://scholarworks.uni.edu/art_facpub/7

This Article is brought to you for free and open access by the Faculty Work at UNI ScholarWorks. It has been accepted for inclusion in Faculty Publications by an authorized administrator of UNI ScholarWorks. For more information, please contact scholarworks@uni.edu. 


\title{
ON VISUAL ART AND CAMOUFLAGE
}

\author{
Roy R. Behrens*
}

In a number of books on visual fine art and design $[1,2]$, there is mention of the kinship between camouflage and painting, but no one has, to my knowledge, pursued it. I have intermittently researched this relationship for several years, and my initial observations have recently been published [3]. Now I have been awarded a faculty research grant from the Graduate School of the University of Wisconsin-Milwaukee to pursue this subject in depth. I am, therefore, collecting documents and personal accounts pertaining to historical and theoretical connections of the kind that are listed below.

Military and natural camouflage are often discussed in terms of the visual distinguishability of an object (e.g. or ship moth) in relation to its background or surroundings [4]. The requirements for distinguishability are included in what perceptual psychologists refer to as figure/ground theory $[1,5,6]$. Generally, the distinguishability of a figure is directly related to (a) the degree to which its components are visually homogeneous, and (b) the extent to which the figure is dissimilar from its surroundings or ground. Effective camouflage may violate one or both conditions through such techniques as blending, in which the color or other properties of the figure tend to resemble the characteristics of the background; disruptive patterning, in which the integrity of the figure is weakened by the visual heterogeneity of its components; countershading, in which a 3-dimensional figure bears a pattern of gradation that contradicts the gradation produced by sunlight, making the object look flat; and mimicry, in which the figure imitates the appearance of some other recognizable object. Descriptions and illustrations of these and various other camouflage techniques may be found in the writings of Cott [7-9].

A major breakthrough in the study of natural camouflage occurred in 1896 when Abbott $\mathrm{H}$. Thayer, a painter in the U.S.A., published a paper on The Law Which Underlies Protective Coloration [10]. This was followed in 1902 by a paper on The Meaning of the White Under Sides of Animals [11] and, in 1909, by an influential book on Concealing Coloration in the Animal Kingdom: An Exposition of the Laws of Disguise through Colour and Pattern, the illustration of which was assisted by the author's son, Gerald Thayer, and artists Rockwell Kent and Louis A. Fuertes [12]. The study of natural camouflage, wrote Thayer, "has been in the hands of the wrong custodians ... it properly belongs to the realm of pictorial art, and can be interpreted only by painters. For it deals wholly in optical illusion, and this is the very gist of a painter's life' [12]. Thayer emphasized his discovery of countershading (Thayer's principle), in which the techniques of chiaroscuro are employed in camouflage just as in painting, but with opposite effects-

\footnotetext{
*Designer and teacher, Dept. of Art, University of WisconsinMilwaukee, Milwaukee, WI 53201, U.S.A. (Received 7 Jan. 1978)
}

countershading makes a 3-dimensional object seem flat, while normal shading in flat paintings can make a depicted object appear to be 3-dimensional. He also discussed the function of disruptive patterning, in which even the most brilliant colors may contribute to the destruction of an animal's outline. While Thayer's description of countershading is still respected, his book is considered somewhat fanciful because of exaggerated depictions of figure/ground blending, e.g. in one illustration, a peacock blends in with the sky. More reliable studies of natural camouflage include the writings of Alister Hardy, who thinks it likely 'that there are no finer galleries of abstract art than the cabinet drawers of the tropical butterfly collector' [13], and Hugh B. Cott who (alluding to countershading) notes that, in military and natural camouflage, one finds systems of coloration 'the exact opposite of that upon which an artist depends when painting a picture' [7]. It is significant that both Hardy and Cott are known for their skills as scientific illustrators, and both served as military camouflage officers during World Wars I and II, respectively.

Abbott H. Thayer's writings on natural camouflage may have influenced another artist and student of protective coloration in the U.S.A., George De Forest Brush, who discussed the matter of ship camouflage with the Department of Navy on 3 June 1899. Negotiations between Brush and the U.S. Navy Department continued until August 1911, when the effort was abandoned. Considerations in the U.S.A. of naval camouflage did not resume until 1917, when Brush's son, Gerome Brush, again approached the Navy, and, on 27 June of that year, the Bureau of Construction and Repair ordered the camouflage painting of nine ships [14]. By October 1918, the Navy had applied 'dazzle' patterns to 1,127 ships; while the Engineers Corps had obtained 20 acres of land in Dijon, France, on which was erected a camouflage factory for the production of gun coverings, snipers' suits, dummy heads, silhoue ttes, armor-plated tree trunks and airplane hangar covers. The Dijon factory included a toy shop that served as 'a kind of studio for the painters and sculptors connected with the Fortieth Engineers, which was the camouflage regiment' [15]. In Britain, as early as September 1914, John Graham Kerr had communicated to the First Lord of the Admiralty the methods for applying countershading and disruptive patterns to ships. In France, the first section de camouflage in history was established in 1915, apparently at the urging of a group of French artists. The success of the French section led to the organization of the British camouflage service, a unit of the Royal Engineers, in 1916. In 1940, all but four of the 65 camouflage officers at the British Civil Defense Camouflage Establishment were either professional artists or, at the time of recruitment, had been students in art schools.

In addition to the historical involvement of little known artists in military and natural camouflage, there are 
statements by more widely known artists that note the resemblance between the disruptive patterning used in camouflage and the fragmentation manner used by some painters. For example, there is an interview with Georges Braque in which he states: 'I was happy when, in 1914, I realized that the Army had used the principles of my cubist paintings for camouflage. "Cubism and camouflage", I once said to someone. He answered that it was all a coincidence. "No, no", I said, "it is you who are wrong. Before Cubism we had Impressionism, and the Army used pale blue uniforms, horizon blue, atmospheric camouflage", [16].

Similarly, there is an anecdote about Gertrude Stein and Pablo Picasso. As they were walking one evening in about 1915 on the Blvd. Raspail in Paris: 'A convoy of heavy guns on their way to the front passed them, and they noticed to their astonishment that the guns had been painted with zig-zag patterns to disrupt their outlines. We invented that, exclaimed Picasso, surprised to see that his discoveries in the breaking up of forms should have been pressed so rapidly into military service' [17]. Several years later, Picasso again alluded to disruptive patterning when he said to Jean Cocteau: 'If they want to make an army invisible at a distance they have only to dress their men as harlequins' [17].

The painter Arshile Gorky appears to have become more directly involved with camouflage than any other well known artist in the U.S.A. [18]. In 1941, he wrote to his sister: 'It seems I too shall be called to do camouflage painting. We artists are getting organized so that if called we shall serve as painters and not as soldiers.' When his application to serve as a military camoufleur was denied, Gorky organized a civilian defense course in camouflage at the Grand Central School of Art in New York City. He delivered lectures on protective coloration, optical illusions and gestalt psychology, and constructed designs and models to demonstrate the principles of effective concealment. His advertisement for the course includes the following statements:

'In the study of the object, as a thing seen, he [the artist] has acquired a profound understanding and sensibility concerning its visual aspects. The philosophy as well as the physical and psychological laws governing their relationships constitute the primary source material for the study of camouflage. . . .

'This course is dedicated to that artist, contemporary in his understanding of forces in the modern world, who would use this knowledge in a function of increasing importance. Such an artist will gain a knowledge that will deepen and enrich his understanding of art as well as make him an important contributor to civilian and military defense' [18].

Within similar assumptions, perhaps, the Department of Architecture at Pratt Institute of Art in New York City conducted a civilian defense camouflage research program during World War II.

Camouflage is a relatively neglected aspect of artistic, scientific and military historical studies, and it is especially difficult to trace their interrelations. I would be interested in receiving correspondence regarding other sources and copies of documents, including personal accounts by those who have worked with military camouflage, and examples of contemporary art that employ camouflage techniques [19].

\section{References}

1. R. Arnheim, Art and Visual Perception (Berkeley: Univ. of California Press, 1974).

2. C. Harlan, Vision and Invention (Englewood Cliffs, N.J.:Prentice-Hall, 1970).

3. R. R. Behrens, Camouflage, Cubism, and Creativity: The Dissolution of Boundaries, $J$. Creative Behavior 11, 91 (1977).

4. R. G. Coss, The Ethological Command in Art, Leonardo 1, 273 (1968).

5. E. H. Gombrich, J. Hochberg, and M. Black, Art Perception, and Reality (Baltimore: Johns Hopkins Univ. Press, 1972)

6. J. J. Gibson, Information Available in Pictures, Leonardo 4, 27 (1971).

7. H. B. Cott, Camouflage in Nature and in War, Royal Engineers $J .$, p. 501 (1938).

8. H. B. Cott, Animal Form in Relation to Appearance, in L. L. Whyte, ed., Aspects of Form (Bloomington:Indiana Univ. Press, 1966).

9. H. B. Cott, Adaptive Coloration in Animals (London: Methuen, 1940).

10. A. H. Thayer, The Law Which Underlies Protective Coloration, Auk 13, 124 (1896).

11. A. H. Thayer, The Meaning of the White Under Sides of Animals, Nature, p. 596 (April 1902).

12. G. H. Thayer, Concealing Coloration in the Animal Kingdom (New York: Macmillan, 1918).

13. A. Hardy, The Living Stream (New York: Harper and Row, 1965).

14. R. F. Sumrall, Ship Camouflage (WWI): Deceptive Art, Proc. U.S. Naval Institute 97, 57 (1971).

15. America's Munitions 1917-1918. Report of the Assist. Sec. of War (Washington D.C.: Government Printing Office, 1919).

16. A. Liberman, The Artist in His Studio (New York: Viking Press, 1969).

17. R. Penrose, Picasso: His Life and Work (New York: Harper and Row, 1973).

18. E. K. Schwabacher, Arshile Gork y (New York: Macmillan, 1957).

19. For assistance in my research of military camouflage, I am especially indebted to Mrs. Elsie F. Dupre, Optical Science Division, Naval Research Laboratory, Washington, D.C., U.S.A. 